\title{
Proposed Office Facilities Layout in Low Voltage Electric Panel Manufacturer
}

\author{
Julliete Angel Luin ${ }^{1 *}$, Josephine Angel Luin ${ }^{2}$ \\ ${ }^{1}$ Department of Industrial Engineering, Universitas Bunda Mulia, Jl. Lodan Raya No. 2 Ancol, North Jakarta \\ 14430, Indonesia \\ ${ }^{2}$ International Business Department, Faculty of Business, Yangzhou University, 88 Daxue South Road, \\ Yangzhou City, Jiangsu Province, China
}

Received: 2 December, 2020 / Accepted: 1 February, 2021

\begin{abstract}
The electrical equipment industry in Indonesia is one of the factors that triggers economic growth. Labor productivity determines the success of project implementation. The non-optimal facility layout is one of the factors that triggers low labor productivity. The non-optimal facility layout affects the flow of information in the company. This study examines the problem of non-optimal office facility layout with TSP, ARC and ARD methods at PT. Duta Wijaya Elektrindo Engineering (PT. DWP). The method stated above can minimize the total distance traveled between office facilities so that work efficiency and workforce productivity may increase. The results of data processing indicate that the recommended office facility layout recommendations that are in accordance with the level of closeness between departments based on PST, ARC and ARD is the first recommendation. With reduced total distance traveled in the first layout of the proposed office facilities, the level of employee productivity and work efficiency will increase. The smallest total distance traveled on the proposed layout of the office facilities is 244.22 meters with a reduction of $36 \%$ from the initial conditions.
\end{abstract}

Keywords: Layout, Facility, Activity Relationship Chart, Activity Relationship Diagram, Priority Scale Table, Distance traveled

\section{INTRODUCTION}

The electrical equipment industry in Indonesia is one of the triggers for economic growth. The production of electricity supporting electricity equipment is directly proportional to the increasing demand for the national electricity (Kurangi Ketergantungan Impor Peralatan Listrik, Industri Substitusi Harus Didorong, 2017; Darmono, 2019). As the demand keeps increasing, it is logical that the competition between manufacturers is going to be incisive (Nurprihatin, Angely and Tannady, 2019). This demand should be managed and fulfilled through a set of activities and requires internal coordination and continuous improvement (Andry, Tannady and Nurprihatin, 2020; Gunawan et al., 2020) Hence, the company must do continuous improvement in all aspects to gain the achievement (Nurprihatin, Jayadi and Tannady, 2020). Furthermore, the business performance in the particular sector can reflect the economic structure (Christian et al., 2021).

There was an increase in export value and investment value from 2017 to 2018 in the electronics industry of US\$ 0.3 billion and US\$ 5.05 billion. This is supported by an increase in the proportion of workers from 2016 to 2019 in the electrical equipment industry sector by 41.67\%. Expenditures for labor from 2014 to 2017 in the electrical equipment industry sector increased by $40.51 \%$ or 2.646 billion rupiahs (Siregar, 2019; Badan Pusat Statistik, 2020a, 2020b).

Industrial growth needs to be supported by electricity infrastructure. An increase in the use of linear digital technology with a 2 to 3 -fold increase in load capability in electrical substations. With this, Indonesia has the opportunity to build an electric panel industry to support the use of digital technology in encouraging industry 4.0 (Makmun, 2018).

*email: jullieteluin@gmail.com 


\section{Electronics Industry}

15

10

5

0

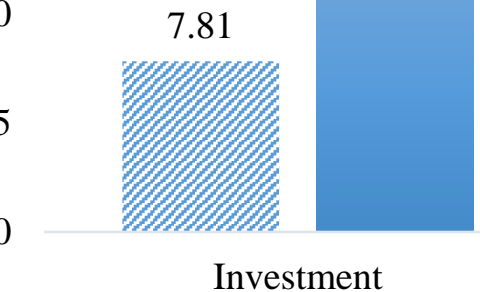

12.86

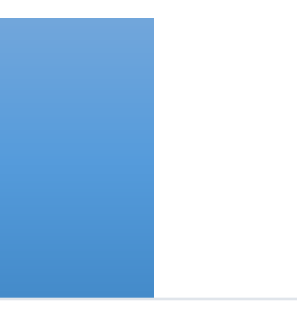

Investment

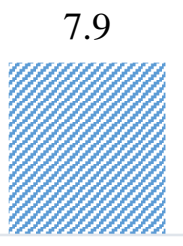

8.2

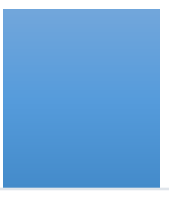

Export

Figure 1. Increase in Export Value and Investment in the Electronics Industry

(Source: Siregar, 2019)

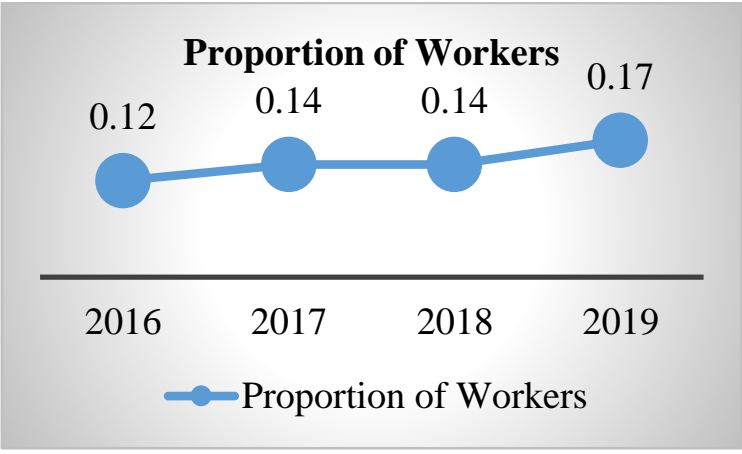

Figure 2. Increase in the Proportion of the Workforce in the Electrical Equipment Industry (Source: Badan Pusat Statistik, 2020)

Labor productivity determines the success of project implementation. The increase in labor productivity is an indicator of achieving high competitiveness and driving national economic growth in the long term (International Labor Organization, 2016; Kementerian Ketenagakerjaan Republik Indonesia, 2016; Marlita, 2017). Work productivity is expected to be carried out effectively and efficiently to achieve the desired goals (Asnora, 2020; Karima, Khamim and Setiono, 2020).

Low labor productivity can be triggered by various factors. Labor productivity in Indonesia is the second-lowest in ASEAN (Pransuamitra, 2019). Indonesia will experience a demographic bonus period in 2045 so it requires qualified human resources. In 2020, there are 185.34 million people of productive age (15 - 64 years) and it is projected to continue to grow to 318.96 million people by 2045 (Anggit, 2019). Human resources with productive age can be an advantage by improving education and quality so that they can

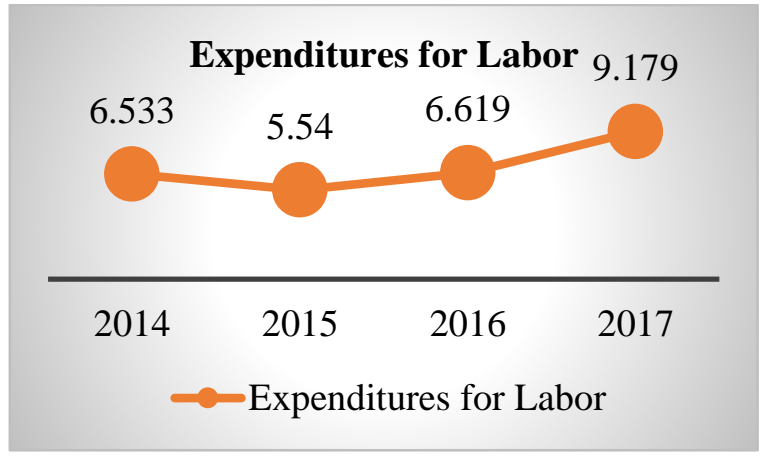

Figure 3. Increased Expenditure on Labor in the Electrical Equipment Industry

(Source: Badan Pusat Statistik, 2020)

compete later. At that time, the dependency ratio for the population was 45.46; This means that every 100 people of productive age have 46 people of unproductive age dependents. Labor productivity is expected to increase along with the quality of human resources that continues to be improved (Badan Pusat Statistik, 2018; Pransuamitra, 2019).

The non-optimal facility layout is one of the factors that triggers low labor productivity. A good work environment will result in high labor productivity and vice versa. Modernizing processes and systematizing workflows in factories is one of the most effective ways to help companies achieve optimal efficiency (Chandra, 2019; Maulina, 2019). The layout of the facility has a huge impact on employee performance and positively affecting workforce productivity; proven by an increase in organizational performance of up to 15 percent (Franklin, 2019; HRnews, 2020). The change in the layout of office facilities creates a work environment that revitalizes communication, 
improves the quality of work, and encourages higher productivity (Inamizu, 2015; Business Matters, 2020; Paljug, 2020).

The non-optimal facility layout affects the flow of information in the company. The flow of information cannot flow properly to a nonoptimal facility layout which can affect working time and reduce labor productivity (Fajrilah, Aviasti and Nu'man, 2017; Putri, 2019). Delays and increases in production costs are caused by inadequate flow of information and material patterns as well as the relatively high movement of materials (Apple, 1990; Sofyan and Syarifuddin, 2015). A study discussed an effort to minimize cost in terms of logistics cost (Nurprihatin et al., 2021) considering the mode of transportation, and the capacity of each mode of transportation (Nurprihatin, Regina and Rembulan, 2021).

There are various methods for optimizing the facility layout. BLOCPLAN and Analytical Hierarchy Process (AHP) methods are used to select the best alternative facility layout (Fajrilah, Aviasti and Nu'man, 2017; Daya, Sitania and Profita, 2018). A previous study has been conducted to minimize the travel distance (Nurprihatin, Octa, et al., 2019). Systematic layout planning is used to change the layout of the facility by minimizing the material/information flow distance to increase labor productivity and reduce costs (Muslim and Ilmaniati, 2018; Siahaan and Oktiarso, 2018; Lasut, Rottie and Kairupan, 2019). The Computerized Relative Allocation of Facilities Techniques (CRAFT) algorithm overcomes material flow barriers and improper operation resulting from ineffective facility layout designs (Maheswari and Firdauzy, 2015; Tahir, Syukriah and Baidhawi, 2015; Hidayat and Ariyono, 2017; Lekan, Kayode and Morenikeji, 2017). The optimal facility layout can reduce the distance to ship goods using a heuristic search algorithm based on biological evolution mechanisms (Goldberg, 1989; Holland, 1992). The 5S method (Seiri, Seiton, Seiso, Seiketsu \& Shitsuke) is used to get a tidier layout of the facility to improve the efficiency of material flow and workflow (Sofyan and Syarifuddin, 2015; Putri and Ismanto, 2019). The integration of the four lean methods (tact-time design, channel balance, mobile design, and one-part flow) can significantly increase efficiency, reduce costs and improve more key performance indicators (Kovács, 2019).

Priority Scale Table (PST), Activity Relationship Chart (ARC), and Activity Relationship Diagram (ARD) can determine the optimal facility layout by analyzing the level of linkages between facilities. The method above can minimize the total distance traveled by $48.8 \%$ from the current condition in previous studies (Winarno, 2015; Hamdani, Herlina and Kurniawan, 2016; Safirtri et al., 2017). Transportation is one of a waste that should be eliminated or minimized (Tannady et al., 2019). If it is cannot be eliminated, it could be dangerous (Nurprihatin, Elnathan, et al., 2019) and make the company experiencing losses (Andiyan et al., 2021).

This study examines the problem of nonoptimal office facility layout with PST, ARC, and ARD methods at PT. Duta Wijaya Elektrindo Engineering (PT. DWP). The method above is expected to minimize the distance between office facilities so that work efficiency and labor productivity increase. Furthermore, a work environment has a positive and significant effect to increase the work motivation of employees (Tannady, Erlyana and Nurprihatin, 2019). The work environment is all the facilities and infrastructure used and felt by an employee when working, and this greatly affects work practices (Tannady, Andry and Nurprihatin, 2020).

\section{METHODOLOGY}

This research begins by identifying the data that needs to be processed to solve the problem as shown in Figure 4. The research data is divided into three types, namely business process flow, total distance traveled between departments, and initial condition office facility layout. The data that has been collected is then processed using methods based on theory (PST, ARC \& ARD) assisted by computer software, namely Microsoft Excel and Visio. The research ends by providing conclusions and suggestions. The conclusion is to answer the formulation of the problem that is adjusted to the results obtained in the research and suggestions are given to related parties or researchers to carry out further research. 


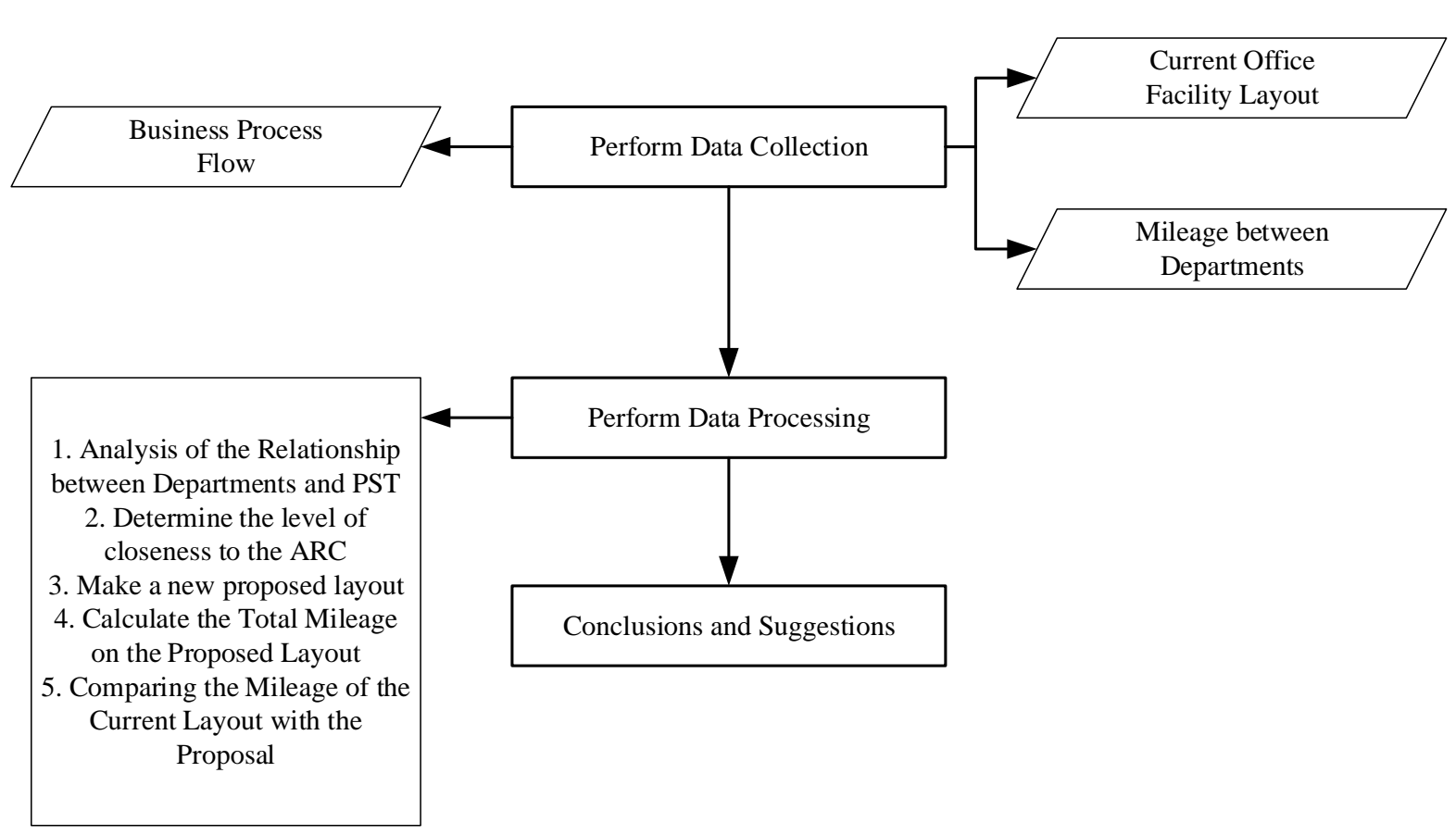

(Source: Researcher, 2020)

Figure 4. Research Flow Chart

The object of this research is the layout of the office facilities of a low voltage electrical panel manufacturing company. Data collection is done is collecting primary data by making direct observations in the field. Direct interviews with company representatives were conducted to obtain primary data.

\subsection{Labor Productivity}

Productivity is the ability to get many benefits by producing optimal results (Siagian, 2015; Aprilyanti, 2019). Labor productivity can be calculated by looking at the ratio of total output to hours worked (Irfan et al., 2020). In addition, labor productivity can be measured by the quantity of production or work done (Mangkunegara, 2009; Umar, 2018).

\subsection{Facility Layout}

Facility layout is the arrangement of each facility to perform a job such as producing products and providing services. Services are actions or performances that can be done by one party to another (Tannady, Nurprihatin and Hartono, 2018). Facility layout design, conceptualizes, designs, and realizes a system for making goods or services to optimize the relationship between operators, the flow of goods, information flow, and procedures needed to achieve business goals effectively, efficiently, economically, and safely (Apple, 1990). Designing an effective facility layout can significantly reduce the company's operational costs and can result in increased performance on the production line (Kovács and Kot, 2017). The cost is approximated by the distance between two points (Nurprihatin and Tannady, 2018).

\subsection{Information Flow}

Information flow is needed to convey messages to the organization both internally and externally. Information flow requires planning in the preparation of appropriate messages and strategic channels to convey messages accurately. This is done to introduce and explain something to the audience, achieving the expected targets, influencing the viewpoints and behavior of the target audience, and relating to the community. 


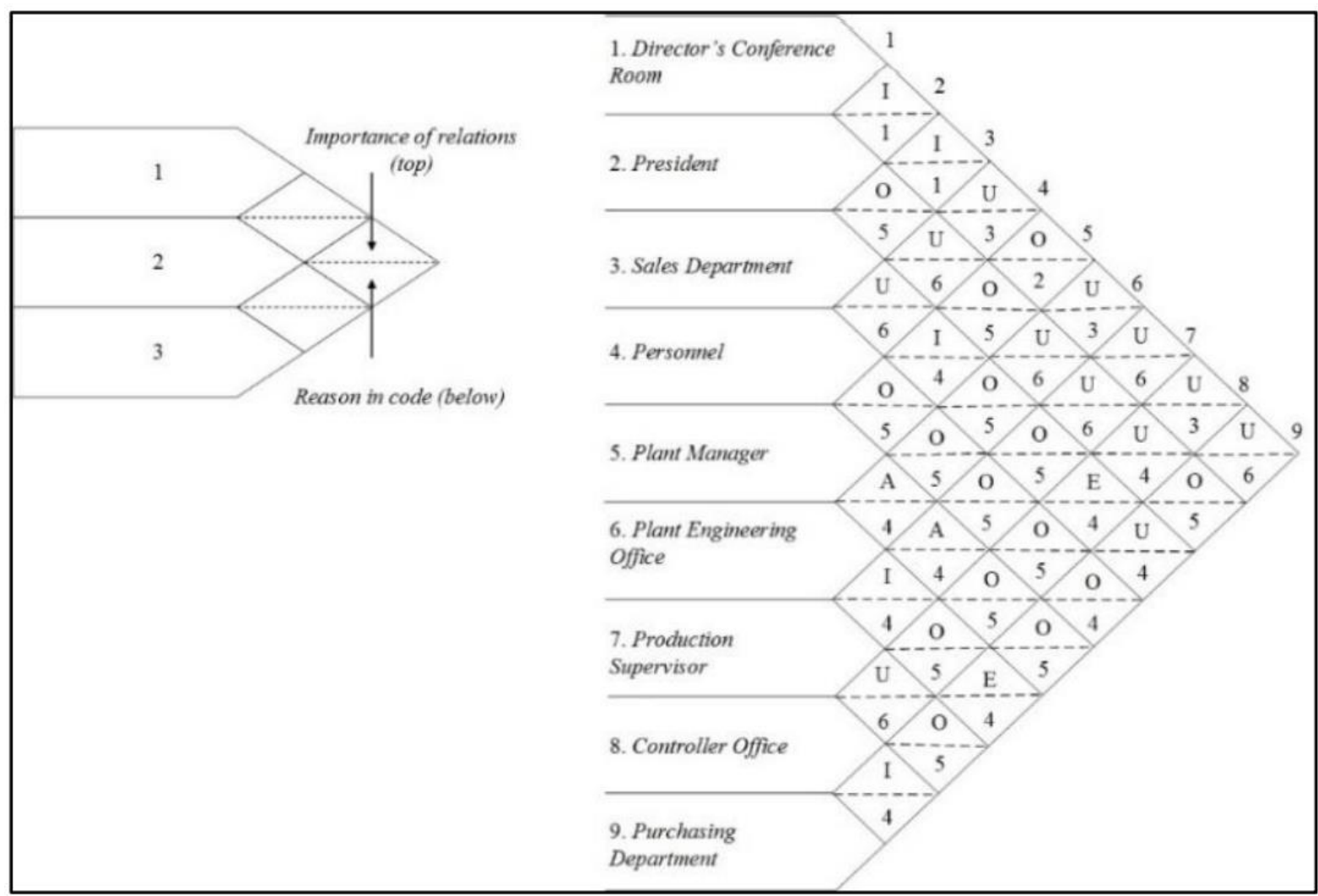

Figure 5. Example of an Activity Relationship Chart

(Source: Apple, 1990; Tompkins, White, Bozer, Thompkins, \& White, 2010)

\subsection{Priority Scale Table}

The priority scale table is a table that describes the order of priority between departments/machines in a production line (Apple, 1990; Lasut, Rottie and Kairupan, 2019; Kebela et al., 2020) The objectives of making priority scale tables include minimizing costs, minimizing total distance traveled, and optimizing the layout (Apple, 1990). The base for making ARC and ARD is a priority scale table, so that which occupies the priority in the priority scale table must be closer to its location then followed by the next priority (Apple, 1990).

\subsection{Activity Relationship Chart (ARC)}

Activity Relationship Chart (ARC) is a technique used to analyze the level of relationship or linkage between each facility/department/activity (Apple, 1990). ARC uses several letter symbols such as a scale as a marker of the degree of closeness and several consecutive number symbols as a proxy for the use of the letter degree symbol (Apple, 1990; Wignjosoebroto, 2003; Kasilingam, 2011; Safirtri et al., 2017). Figure 5 shows that ARC can emphasize the closeness of the relationship between departments and their suitability (Apple, 1990; Tompkins, White and Bozer, 2010). The explanation of the letter and number symbols in the application of the Activity Relationship Chart (ARC) method can be seen in Table 1 (Tompkins, White and Bozer, 2010; Hillier and Lieberman, 2015).

Table 1. ARC Proximity Symbol

\begin{tabular}{clcl}
\hline Value & \multicolumn{1}{c}{ Closeness } & Code & \multicolumn{1}{c}{ Reason } \\
\hline $\mathbf{A}$ & $\begin{array}{l}\text { Absolutely } \\
\text { Necessary }\end{array}$ & 1 & $\begin{array}{l}\text { Frequency of } \\
\text { Use High }\end{array}$ \\
\hline $\mathbf{E}$ & $\begin{array}{l}\text { Especially } \\
\text { Important }\end{array}$ & 2 & $\begin{array}{l}\text { Frequency of } \\
\text { Use Medium }\end{array}$ \\
\hline $\mathbf{I}$ & $\begin{array}{l}\text { Important } \\
\text { Frequency of } \\
\text { Use Low }\end{array}$ \\
$\mathbf{O}$ & $\begin{array}{l}\text { Ordinary } \\
\text { Closeness } \\
\text { Okay }\end{array}$ & 4 & $\begin{array}{l}\text { Information } \\
\text { Flow High }\end{array}$ \\
$\mathbf{U}$ & Unimportant & 5 & $\begin{array}{l}\text { Information } \\
\text { Flow Medium }\end{array}$ \\
\hline $\mathbf{X}$ & Undesirable & 6 & $\begin{array}{l}\text { Information } \\
\text { Flow Low }\end{array}$ \\
\hline
\end{tabular}

(Source: Hillier \& Lieberman, 2010; Tompkins et al., 2010) 
In determining the number of relationships between facilities, equation (1) is the formula used (Tompkins, White and Bozer, 2010):

$$
N=\frac{(n-1)}{2}
$$

where:

$n=$ Number of Facilities/Departments

$N=$ Number of connections between facilities

After knowing the number of relationships between facilities, Table 2 provides information on the number of each proximity value that needs to be considered in designing the facility layout. (Tompkins, White and Bozer, 2010).

Table 2. Weight of ARC Value

\begin{tabular}{cc}
\hline Value & Weight of Value \\
\hline $\mathbf{A}$ & $5 \%$ of $N$ \\
$\mathbf{E}$ & $10 \%$ of $N$ \\
$\mathbf{I}$ & $15 \% \mathrm{f} N$ \\
$\mathbf{O}$ & $25 \%$ of $N$ \\
$\mathbf{U}$ & Remaining $\%$ of $N$ \\
$\mathbf{X}$ & Remaining \% of $N$ \\
\hline
\end{tabular}

(Source: Tompkins et al., 2010)

\subsection{Activity Relationship Diagram (ARD)}

Activity Relationship Diagram (ARD) is made based on the priority scale and ARC. ARD is the basis for planning the relationship between material flow patterns and the departments associated with the activities carried out (Apple, 1990; Wignjosoebroto, 2003; Muther and Hales, 2015; Assiddiqi, 2016; Rosyidi, 2018). Several things that must be considered in making ARD, among others (Apple, 1990; Wignjosoebroto, 2003; Muther and Hales, 2015; Stephens and Matthew P. Stephens, 2019):

1. ARD is composed of several squares with a degree of closeness to form a good arrangement.

2. The degree of proximity that has been determined must be considered in terms of laying out the various existing facilities, for example:

a. The degree of proximity A, means that the facilities must be right next to each other.

b. The degree of proximity $\mathrm{E}$ means that the maximum distance between facilities is 1 square. c. The degree of proximity I means that the maximum distance between facilities is 2 boxes, etc.

3. ARD line drawing rules:

Degree A: 4 red lines.

Degree E: 3 yellow lines.

Degree I: 2 dark green lines.

Degree O: 1 dark blue line.

U degree: no mark.

$\mathrm{X}$ degree: 1 brown ridged line.

Figure 6 shows an example of an ARD form.

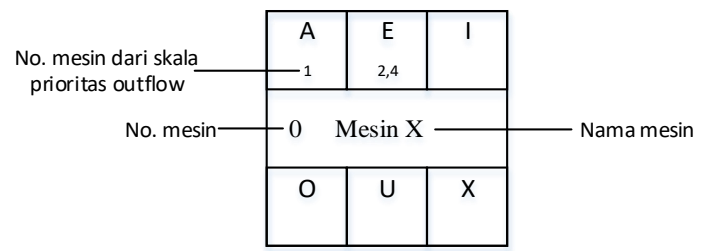

Figure 6. ARD Form

(Source: Wignjosoebroto, 2003)

\section{RESULTS AND DISCUSSION}

\subsection{Business Process Flow}

A business process describes a collection of activities or stages that a company goes through from project start to completion. Through the flow of business processes, it can be seen which departments/divisions are very influential and interrelated in the continuity of the company. The business process flow is shown through the flowchart as shown in Figure 7.

\subsection{Facilities}

Overall, the company has 20 facilities which can be seen in Table 3. Referring to the business processes that have been described previously, only the leadership room up to QC/testing will be further reviewed.

\subsection{Layout of Office Facilities}

The land area owned by the company, amounting to $5,084,7015 \mathrm{~m}^{2}$. Figure 8 shows the initial layout of the company.

\subsection{Initial Distance Traveled Between Related Departments}

The distance between departments can be seen in Table 4. Based on Table 4, can be seen that the total distance traveled between related departments at the company is $382.03 \mathrm{~m}$. The displacement from the leader's office is $\mathbf{1 1 7 . 3 2}$ $\mathrm{m}$, the movement from marketing (sales) is 
$34.59 \mathrm{~m}$, the shift from marketing (estimator) is $68 \mathrm{~m}$, the shift from finance (cash out) is 11.29 $\mathrm{m}$, the shift from procurement is $35,68 \mathrm{~m}$, displacement from the warehouse (component) is $99.14 \mathrm{~m}$, displacement from production area is $0 \mathrm{~m}$ and displacement from PPC/PE is $16 \mathrm{~m}$.

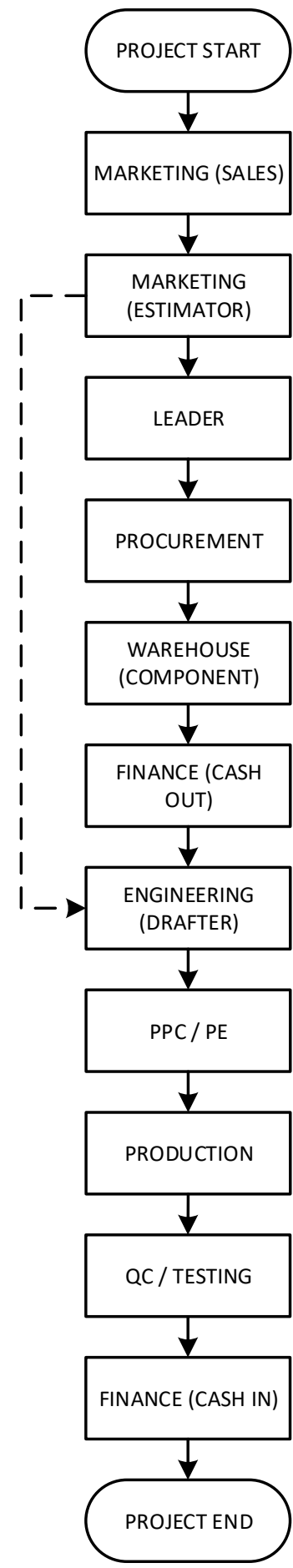

Figure 7. Business Process Flows (Source: Researcher, 2020)
Table 3. Facilities at the Company

\begin{tabular}{cl}
\hline Code & \multicolumn{1}{c}{ Facilities } \\
\hline A & Leader's office \\
$\mathbf{B}$ & Marketing (Sales) \\
$\mathbf{C}$ & Marketing (Estimator) \\
$\mathbf{D}$ & Finance (Cash Out) \\
$\mathbf{E}$ & Finance (Cash In) \\
$\mathbf{F}$ & Procurement \\
$\mathbf{G}$ & Warehouse (Component) \\
$\mathbf{H}$ & Production Area \\
$\mathbf{I}$ & PPC/PE \\
$\mathbf{J}$ & Engineering (Drafter) \\
$\mathbf{K}$ & QC/ Testing \\
$\mathbf{L}$ & HRD \& GA \\
$\mathbf{M}$ & QMR \\
$\mathbf{N}$ & Meeting Room \\
$\mathbf{O}$ & Guest Area \\
$\mathbf{P}$ & Eating Area \\
$\mathbf{Q}$ & Musholla \\
$\mathbf{R}$ & Toilet 1 \\
$\mathbf{S}$ & Toilet 2 \\
$\mathbf{T}$ & Function Hall \\
\hline
\end{tabular}

(Source: Researcher, 2020)

Table 4. Initial Distance Traveled Between Departments

\begin{tabular}{ccc}
\hline Department & $\begin{array}{c}\text { Distance } \\
(\mathbf{m})\end{array}$ & $\begin{array}{c}\text { Closeness } \\
\text { Rating }\end{array}$ \\
\hline A - C & 24,9694 & $\mathrm{E}$ \\
A - B & 54,8823 & $\mathrm{I}$ \\
A - D & 23,0061 & $\mathrm{I}$ \\
A - E & 14,465 & $\mathrm{I}$ \\
B - C & 34,5902 & $\mathrm{E}$ \\
C - D & 3,44 & $\mathrm{I}$ \\
C - E & 22,0261 & $\mathrm{I}$ \\
C - J & 42,5312 & $\mathrm{I}$ \\
D - F & 11,29 & $\mathrm{I}$ \\
F - G & 35,68 & $\mathrm{~A}$ \\
G - H & 34,125 & $\mathrm{E}$ \\
G - K & 65,01668 & $\mathrm{I}$ \\
H - I & 0 & $\mathrm{~A}$ \\
H - K & 0 & $\mathrm{~A}$ \\
H - J & 0 & $\mathrm{I}$ \\
I - J & 9 & $\mathrm{E}$ \\
I - K & 7 & $\mathrm{E}$ \\
\hline Total Distance & & $\mathbf{3 8 2 , 0 3}$ \\
(m) & & \\
\hline
\end{tabular}

(Source: Researcher, 2020) 


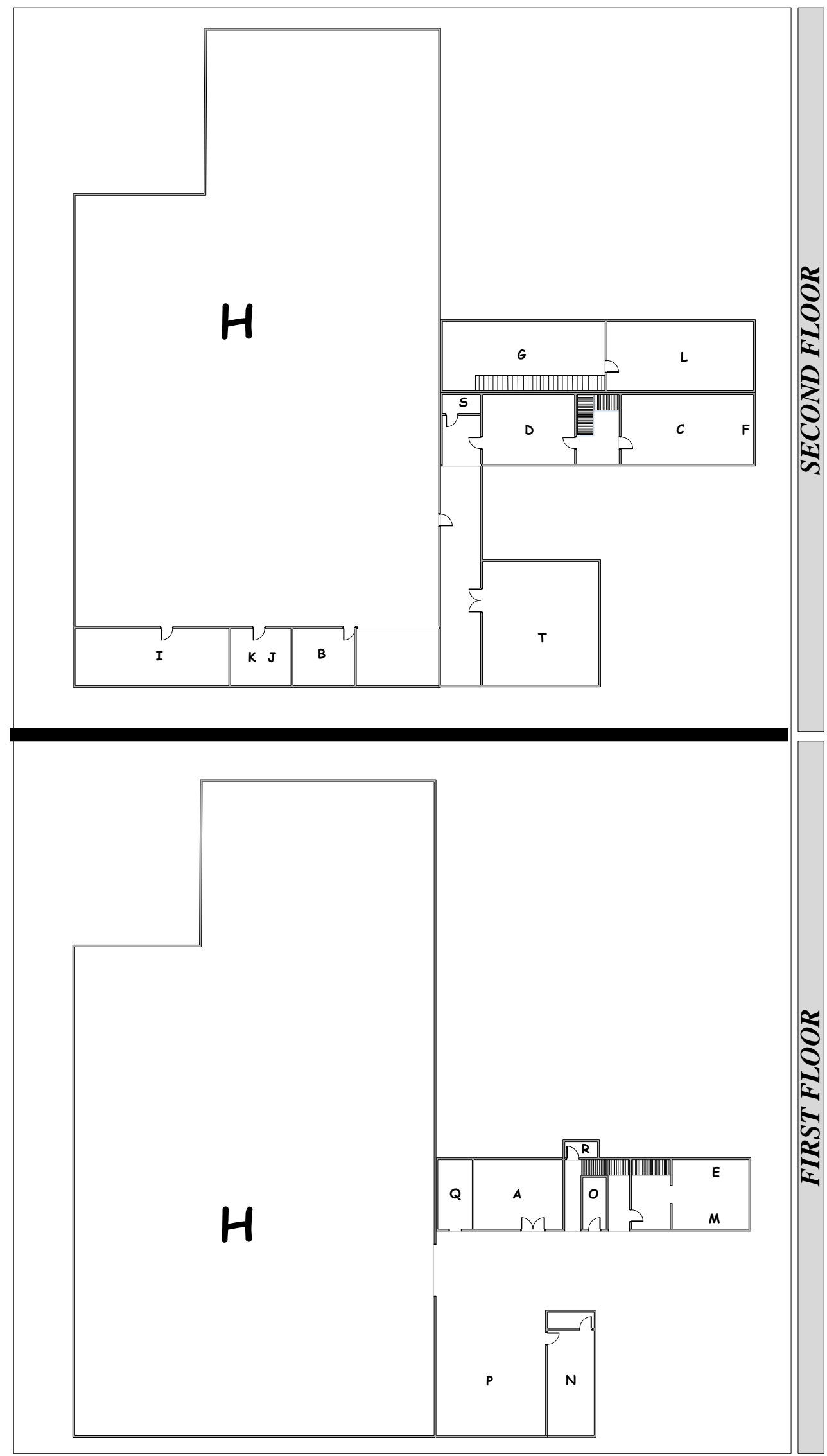

Figure 8 . The Initial Layout of the Company

(Source: Researcher, 2020) 


\begin{tabular}{|c|c|c|c|c|c|c|c|c|c|c|c|}
\hline \\
\hline PT. DWP & $\begin{array}{l}\text { Leader's } \\
\text { Office }\end{array}$ & $\begin{array}{c}\text { Marketing } \\
\text { (Sales) }\end{array}$ & $\begin{array}{l}\text { Marketing } \\
\text { (Estimator) }\end{array}$ & $\begin{array}{c}\text { Finance } \\
\text { (Cash } \\
\text { Out) }\end{array}$ & $\begin{array}{c}\text { Finance } \\
\text { (Cash } \\
\text { In) }\end{array}$ & Procurement & $\begin{array}{l}\text { Warehouse } \\
\text { (Component) }\end{array}$ & $\begin{array}{c}\text { Production } \\
\text { Area }\end{array}$ & PPC/PE & $\begin{array}{c}\text { Engineering } \\
\text { (Drafter) }\end{array}$ & $\begin{array}{c}\text { QC/ } \\
\text { Testing }\end{array}$ \\
\hline $\begin{array}{l}\text { Leader's } \\
\text { Office }\end{array}$ & & I (2) & $\mathrm{E}(1)$ & $\mathrm{I}(2)$ & I (2) & $\mathrm{O}(3)$ & $\mathrm{U}(4)$ & $\mathrm{U}(4)$ & $\mathrm{U}(3)$ & $\mathrm{U}(4)$ & $\mathrm{U}(4)$ \\
\hline $\begin{array}{l}\text { Marketing } \\
\text { (Sales) }\end{array}$ & I (2) & & $\mathrm{E}(1)$ & $\mathrm{O}(3)$ & $\mathrm{O}(3)$ & $\mathrm{O}(3)$ & $\mathrm{U}(4)$ & $\mathrm{U}(4)$ & $\mathrm{O}(3)$ & $\mathrm{U}(4)$ & $\mathrm{U}(4)$ \\
\hline $\begin{array}{l}\text { Marketing } \\
\text { (Estimator) }\end{array}$ & E (1) & E (1) & & I (2) & I (2) & $\mathrm{O}(3)$ & $\mathrm{U}(4)$ & $\mathrm{U}(4)$ & $\mathrm{O}(3)$ & $\mathrm{I}(2)$ & $\mathrm{O}(3)$ \\
\hline $\begin{array}{l}\text { Finance } \\
\text { (Cash Out) }\end{array}$ & I (2) & $\mathrm{O}(3)$ & I (2) & & $\mathrm{O}(3)$ & $\mathrm{I}(2)$ & $\mathrm{U}(4)$ & $\mathrm{U}(4)$ & $\mathrm{O}(3)$ & $\mathrm{O}(3)$ & $\mathrm{U}(4)$ \\
\hline $\begin{array}{l}\text { Finance } \\
\text { (Cash In) }\end{array}$ & I (2) & $\mathrm{O}(3)$ & $\mathrm{I}(2)$ & $\mathrm{O}(3)$ & & $\mathrm{U}(3)$ & $\mathrm{U}(4)$ & $\mathrm{U}(4)$ & $\mathrm{U}(3)$ & $\mathrm{U}(4)$ & U (4) \\
\hline Procurement & $\mathrm{O}(3)$ & $\mathrm{O}(3)$ & $\mathrm{O}(3)$ & I (2) & $\mathrm{U}(3)$ & & A (1) & $\mathrm{U}(3)$ & $\mathrm{O}(3)$ & $\mathrm{U}(4)$ & $\mathrm{U}(4)$ \\
\hline $\begin{array}{l}\text { Warehouse } \\
\text { (Component) }\end{array}$ & $\mathrm{U}(4)$ & $\mathrm{U}(4)$ & $\mathrm{U}(4)$ & $\mathrm{U}(4)$ & $\mathrm{U}(4)$ & A (1) & & $\mathrm{E}(1)$ & $\mathrm{O}(3)$ & $\mathrm{O}(3)$ & $\mathrm{I}(2)$ \\
\hline $\begin{array}{l}\text { Production } \\
\text { Area }\end{array}$ & $\mathrm{U}(4)$ & $\mathrm{U}(4)$ & $\mathrm{U}(4)$ & $\mathrm{U}(4)$ & $\mathrm{U}(4)$ & $\mathrm{U}(3)$ & $\mathrm{E}(1)$ & & A (1) & $\mathrm{I}(2)$ & A (1) \\
\hline PPC/PE & $\mathrm{U}(3)$ & $\mathrm{O}(3)$ & $\mathrm{O}(3)$ & $\mathrm{O}(3)$ & $\mathrm{U}(3)$ & $\mathrm{O}(3)$ & $\mathrm{O}(3)$ & $\mathrm{A}(1)$ & & $\mathrm{E}(1)$ & $\mathrm{E}(1)$ \\
\hline $\begin{array}{l}\text { Engineering } \\
\text { (Drafter) }\end{array}$ & $\mathrm{U}(4)$ & $\mathrm{U}(4)$ & I (2) & $\mathrm{O}(3)$ & $\mathrm{U}(4)$ & $\mathrm{U}(4)$ & $\mathrm{O}(3)$ & I (2) & $\mathrm{E}(1)$ & & $\mathrm{E}(1)$ \\
\hline QC/ Testing & $\mathrm{U}(4)$ & $\mathrm{U}(4)$ & $\mathrm{O}(3)$ & $\mathrm{U}(4)$ & $\mathrm{U}(4)$ & $\mathrm{U}(4)$ & I (2) & $\mathrm{A}(1)$ & $\mathrm{E}(1)$ & $\mathrm{E}(1)$ & \\
\hline
\end{tabular}

(Source: Researcher, 2020) 


\subsection{Priority Scale Table}

The priority scale table in Table 5 shows the relationship between the leader's office, marketing (sales), marketing (estimator), finance (cash out), finance (cash-in), procurement, warehouse (components), production area, PPC/PE, engineering (drafter), and $\mathrm{QC} /$ testing. The determination of the priority scale is supported by reasons that are in accordance with the needs of the company and is also limited by existing provisions (see Table 1 and Table 2).

The following is an example of calculating the provisions for filling in the Priority Scale which will be applied to the Activity Relationship Chart:

$$
\begin{gathered}
N=\frac{n(n-1)}{2} \\
N=\frac{11(11-1)}{2} \\
N=55
\end{gathered}
$$

Description:

$n=$ Number of Facilities/Departments

$N=$ Number of connections between facilities

Table 6. Weight of Value

\begin{tabular}{cc}
\hline Value & Weight of Value \\
\hline $\mathbf{A}$ & $5 \% \times 55=3$ \\
$\mathbf{E}$ & $10 \% \times 55=6$ \\
$\mathbf{I}$ & $15 \% \times 55=9$ \\
$\mathbf{O}$ & $25 \% \times 55=14$ \\
$\mathbf{U}$ \& X & $55-32=23$ \\
\hline
\end{tabular}

(Source: Researcher, 2020)

Table 7. The Reason on the PST

\begin{tabular}{cl}
\hline No. & \multicolumn{1}{c}{ Reason } \\
\hline $\mathbf{1}$ & Information Flow High \\
$\mathbf{2}$ & Information Flow Medium \\
$\mathbf{3}$ & Information Flow Low \\
$\mathbf{4}$ & Unrelated One with Another \\
\hline
\end{tabular}

(Source: Researcher, 2020)

\subsection{Activity Relationship Chart (ARC)}

The proximity relationship that has been processed in Table 5 is the base for making ARC which can be seen in Figure 9. The determination of the ARC is done by asking for consideration from the management represented by the company leadership.

\subsection{Activity Relationship Diagram (ARD)}

Data on the proximity relationship based on ARC is processed into ARD so that the layout of the proposed office facilities can be simulated by taking into account the proximity relationship. Figure 10 shows the ARD at the company.

The results of the ARD can be applied as a reference in determining the layout of the proposed office facilities for the company because the related office/department facilities have been placed according to their proximity.

\subsection{Proposed Office Layout}

Based on the results of data processing in the previous stage, a proposed office facility layout is obtained that can be applied to minimize the distance between departments. Based on all the processing and aspects that are considered as well as existing limitations, 3 proposed office facility layouts were obtained which could be a solution for the company to fix problems that existed in the layout of the initial office facilities at the company by minimizing the distance between related departments. Figures 11,12, and 13 represent the three layouts of the proposed office facilities, respectively. 


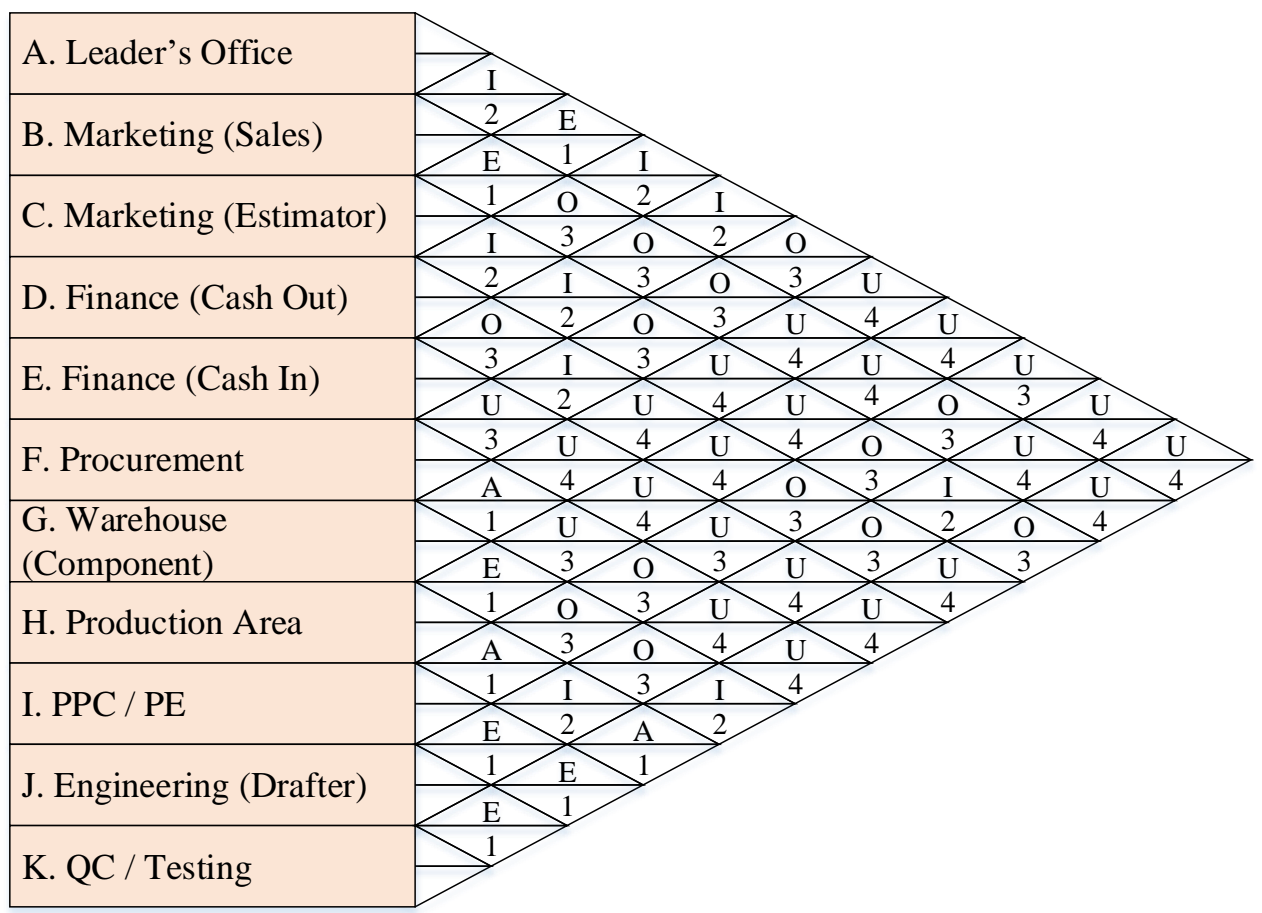

Figure 9. Activity Relationship Chart

(Source: Researcher, 2020)

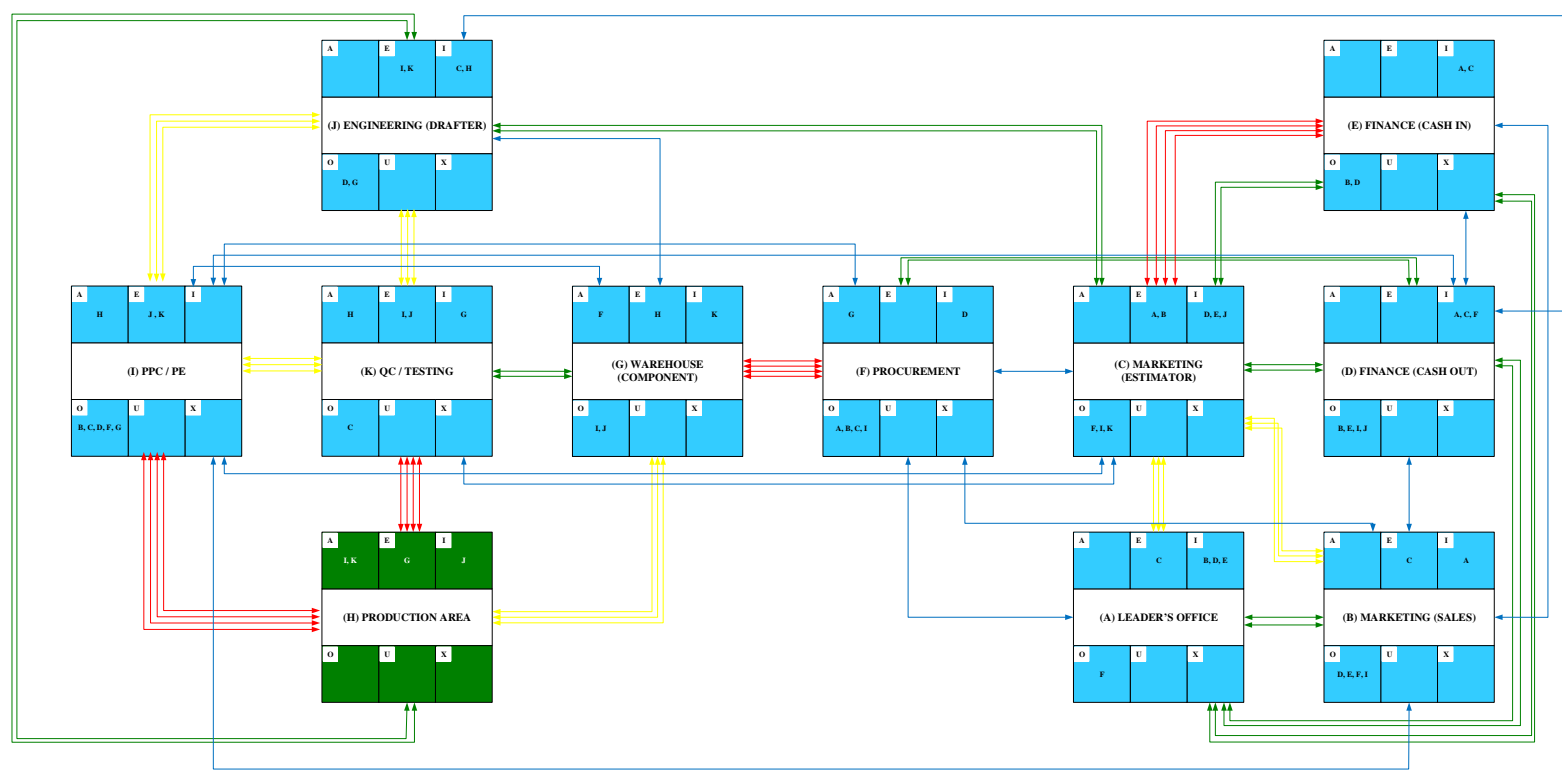

Figure 10. Activity Relationship Diagram

(Source: Researcher, 2020) 


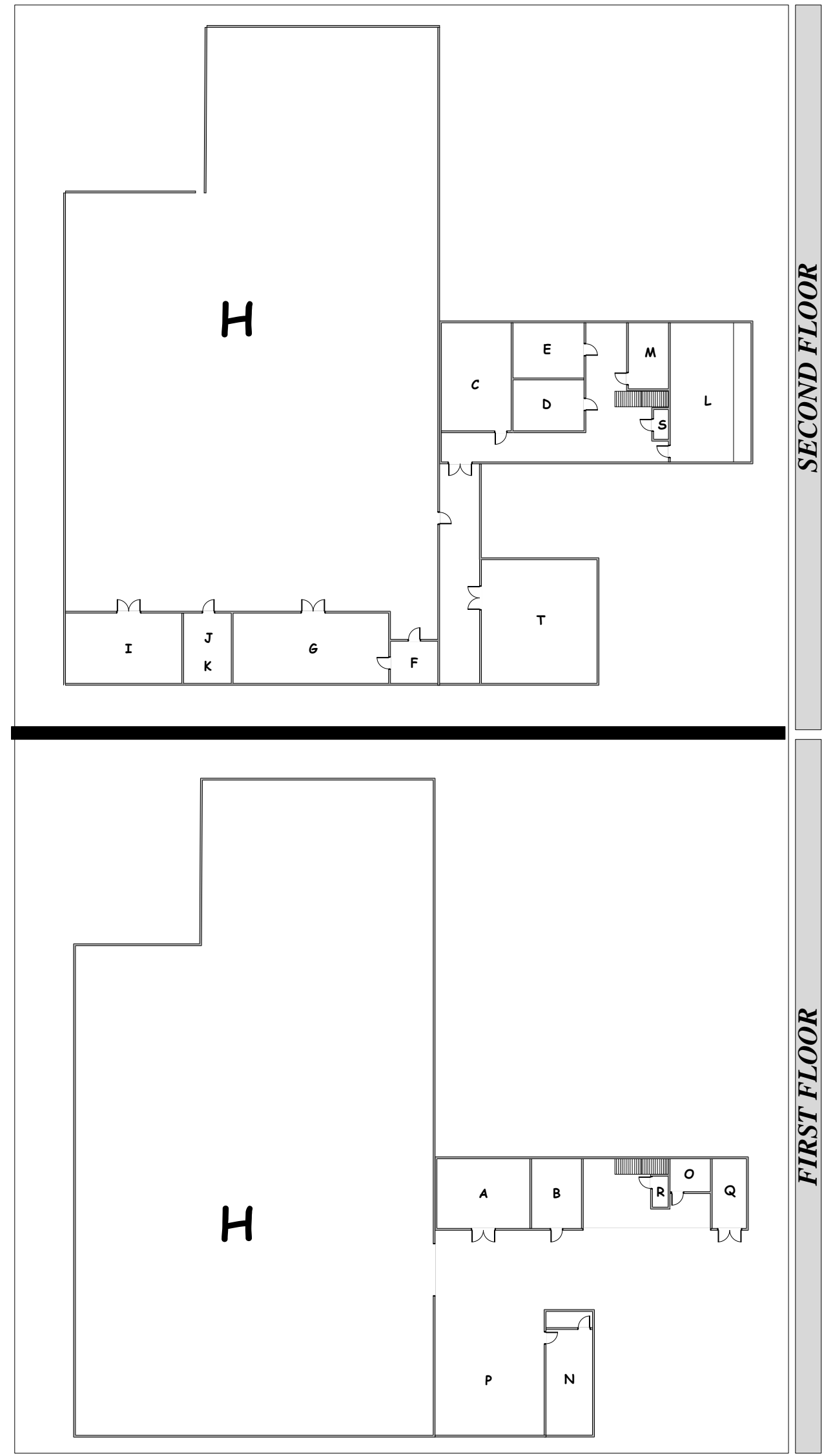

Figure 11. Layout of Proposed Office Facilities 1

(Source: Researcher, 2020) 
Versi Online:

http://journal.ubm.ac.id/index.php/jiems DOI: 10.30813/jiems.v14i1.2410

Hasil Penelitian
Journal of Industrial Engineering and Management Systems Vol. 14, No. 1, 19-37, 2021 ISSN 1979-1720 E-ISSN 2579-8154

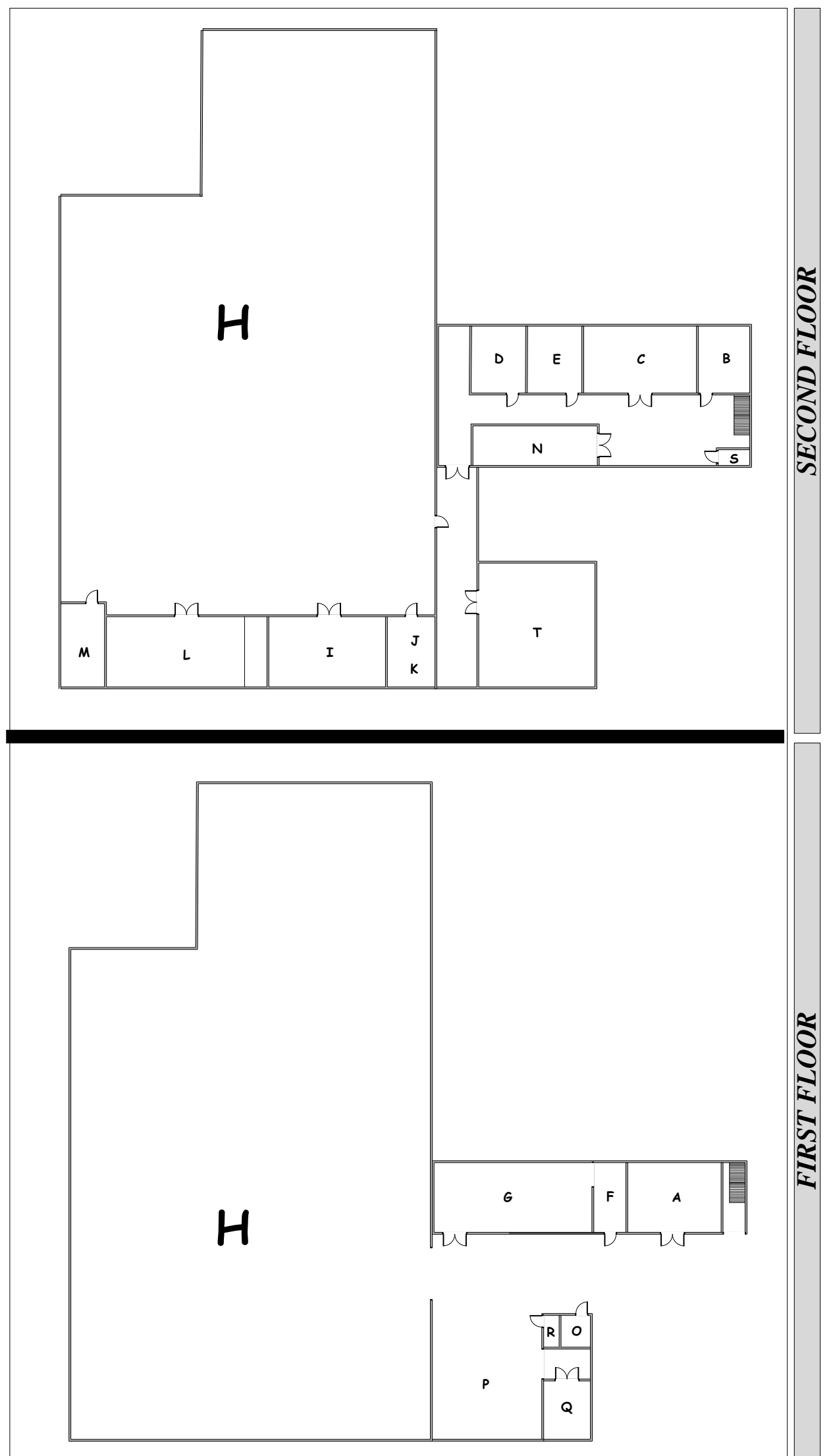

Figure 12. Layout of Proposed Office Facilities 2

(Source: Researcher, 2020) 


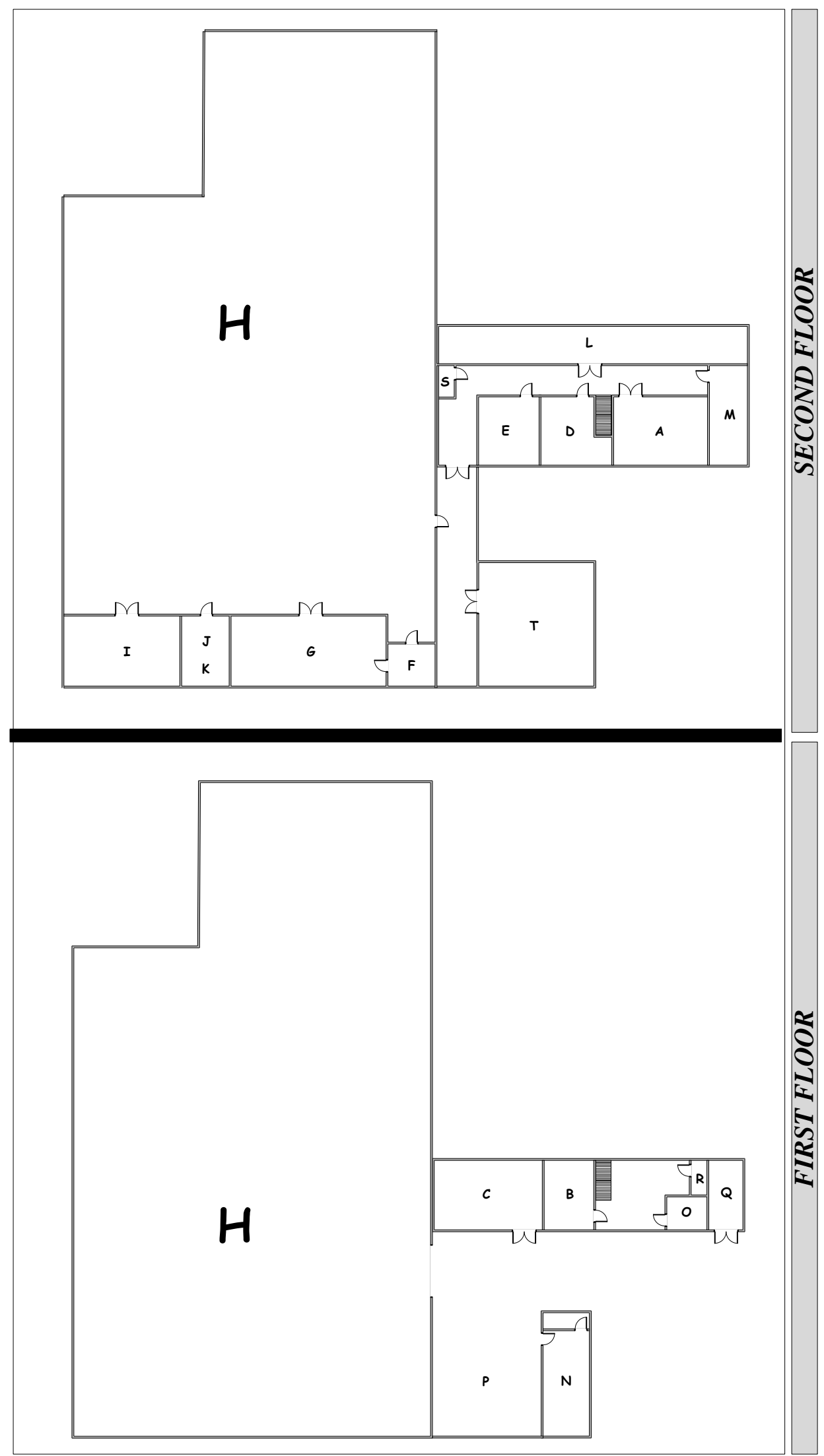

Figure 13. Layout of Proposed Office Facilities 3

(Source: Researcher, 2020) 


\subsection{Proposed Distance Traveled between Related Departments}

The following is a table for calculating the total distance traveled between related departments of the three proposed office facility layouts.

Table 8. Calculation of Distance Traveled Between Departments Condition of Proposal 1

\begin{tabular}{|c|c|c|}
\hline Departments & $\begin{array}{c}\text { Distance } \\
\text { (m) }\end{array}$ & $\begin{array}{c}\text { Closeness } \\
\text { Rating }\end{array}$ \\
\hline$A-C$ & 28,8879 & $\mathrm{E}$ \\
\hline $\mathbf{A}-\mathbf{B}$ & 5,6761 & I \\
\hline A - D & 27,0929 & I \\
\hline$A-E$ & 31,0479 & I \\
\hline B - C & 23,335 & $\mathrm{E}$ \\
\hline C - D & 9,175 & I \\
\hline$C-E$ & 12,85 & I \\
\hline $\mathbf{C}-\mathbf{J}$ & 36,4114 & I \\
\hline D - F & 32,1307 & I \\
\hline F - G & 10,1058 & A \\
\hline $\mathbf{G}-\mathbf{H}$ & 0 & $\mathrm{E}$ \\
\hline $\mathbf{G}-\mathbf{K}$ & 12,25 & I \\
\hline H - I & 0 & A \\
\hline H - K & 0 & A \\
\hline $\mathbf{H}-\mathbf{J}$ & 0 & I \\
\hline $\mathbf{I}-\mathbf{J}$ & 6,1886 & $\mathrm{E}$ \\
\hline $\mathbf{I}$ - $\mathbf{K}$ & 9,0636 & $\mathrm{E}$ \\
\hline $\begin{array}{l}\text { Total Distance } \\
\text { (m) }\end{array}$ & \multicolumn{2}{|c|}{244,22} \\
\hline
\end{tabular}

(Source: Researcher, 2020)

Based on Table 8, the layout of the first proposed office facilities has a total distance traveled of 244.22 meters. The total distance traveled of the proposed office facility layout is smaller than the initial total distance traveled of 382.03 meters. So, it can be concluded that the application of the PST, ARC, and ARD methods succeeded in reducing the total distance traveled by $36 \%$.

Based on Table 9, the proposed second office facility layout has a total distance traveled of 313.25 meters. The total distance traveled of the proposed second office facility layout is smaller than the initial total distance traveled of 382.03 meters. So, it can be concluded that the application of the PST, ARC, and ARD methods succeeded in reducing the total distance traveled by $18 \%$.
Table 9. Calculation of Distance Traveled Between Departments Condition of Proposal 2

\begin{tabular}{clc}
\hline Departments & $\begin{array}{c}\text { Distance } \\
(\mathbf{m})\end{array}$ & $\begin{array}{c}\text { Closeness } \\
\text { Rating }\end{array}$ \\
\hline A - C & 27,175 & $\mathrm{E}$ \\
A - B & 23,375 & $\mathrm{I}$ \\
A - D & 38,975 & $\mathrm{I}$ \\
A - E & 33,835 & $\mathrm{I}$ \\
B - C & 5,1 & $\mathrm{E}$ \\
C - D & 9,85 & $\mathrm{I}$ \\
C - E & 5,25 & $\mathrm{I}$ \\
C - J & 34,85 & $\mathrm{I}$ \\
D - F & 43,535 & $\mathrm{I}$ \\
F - G & 0 & $\mathrm{~A}$ \\
G - H & 0 & $\mathrm{E}$ \\
G - K & 75,725 & $\mathrm{I}$ \\
H - I & 0 & $\mathrm{~A}$ \\
H - K & 0 & $\mathrm{~A}$ \\
H - J & 0 & $\mathrm{I}$ \\
I - J & 6,3504 & $\mathrm{E}$ \\
I - K & 9,2254 & $\mathrm{E}$ \\
\hline Total Distance & & 313,25 \\
(m) & & \\
\hline
\end{tabular}

(Source: Researcher, 2020)

Table 10. Calculation of Distance Traveled Between Departments Condition of Proposal 3

\begin{tabular}{clc}
\hline Departments & $\begin{array}{c}\text { Distance } \\
(\mathbf{m})\end{array}$ & $\begin{array}{c}\text { Closeness } \\
\text { Rating }\end{array}$ \\
\hline A - C & 20,6079 & $\mathrm{E}$ \\
A - B & 20,5829 & $\mathrm{I}$ \\
A - D & 3,7179 & $\mathrm{I}$ \\
A - E & 8,0679 & $\mathrm{I}$ \\
B - C & 7,7 & $\mathrm{E}$ \\
C - D & 20,1052 & $\mathrm{I}$ \\
C - E & 24,4996 & $\mathrm{I}$ \\
C - J & 67,60094 & $\mathrm{I}$ \\
D - F & 32,9408 & $\mathrm{I}$ \\
F - G & 10,016 & $\mathrm{~A}$ \\
G - H & 0 & $\mathrm{E}$ \\
G - K & 13,0897 & $\mathrm{I}$ \\
H - I & 0 & $\mathrm{~A}$ \\
H - K & 0 & $\mathrm{~A}$ \\
H - J & 0 & $\mathrm{I}$ \\
I - J & 7,1886 & $\mathrm{E}$ \\
I - K & 11,0636 & $\mathrm{E}$ \\
\hline \hline Total Distance & & \\
(m) & & \\
\hline
\end{tabular}

(Source: Researcher, 2020) 
Based on Table 10, the third proposed office facility layout has a total distance traveled of 247.19 meters. The total distance traveled of the proposed third office facility layout is smaller than the initial total distance traveled of 382.03 meters. So, it can be concluded that the application of the PST, ARC, and ARD methods succeeded in reducing the total distance traveled by $35 \%$.

According to the three proposed office facility layouts, the first proposal was chosen with a total distance traveled of $244.22 \mathrm{~m}$ with a decrease of $36 \%$ from the initial condition. With reduced distance traveled in the layout of the first proposed office facility, the level of employee productivity and work efficiency will increase (Arija and Perdhana, 2017; Padmantyo, Nursavilla and Ningsih, 2018; Putri and Djalil, 2019; Pramana, 2020).

\section{CONCLUSION}

Based on the results of the analysis, it is concluded that the recommendation for the layout of the proposed office facilities according to the level of closeness between departments based on PST, ARC, and ARD is the first recommendation. With reduced distance traveled in the layout of the first proposed office facility, the level of employee productivity and work efficiency will increase. The smallest total distance traveled on the layout of the proposed office facilities is 244.22 meters with a reduction of $36 \%$ from the initial condition.

Future research can take into account travel time, frequency of movement between departments, wages of workers, and costs of realization. Future research can also calculate the effect of the layout of office facilities on labor productivity and work efficiency so that it can be proven through a qualitative and/or quantitative approach. Finally, further research can consider aspects of the multi-floor facility layout planning.

\section{REFERENCES}

Andiyan, A. et al. (2021) "Construction Project Evaluation Using CPM-Crashing, CPMPERT and CCPM for Minimize Project Delays," Journal of Physics: Conference Series, 1933(1), p. 012096. doi: 10.1088/1742-6596/1933/1/012096.

Andry, J. F., Tannady, H. and Nurprihatin, F. (2020) "Eliciting Requirements of Order Fulfilment in a Company," in IOP
Conference Series: Materials Science and Engineering, pp. 1-6. doi: 10.1088/1757899X/771/1/012023.

Anggit, I. (2019) Menteri Bappenas Sebut Produktivitas Tenaga Kerja RI Rendah, CNBC Indonesia.

Apple, J. M. (1990) Tata Letak Pabrik Dan Pemindahan Bahan. Bandung: ITB Bandung.

Aprilyanti, S. (2019) "Pengaruh Usia dan Masa Kerja terhadap Produktivitas Kerja (Studi Kasus: PT. Oasis Water International Cabang Palembang)," Jurnal Sistem dan Manajemen Industri, 1(2), pp. 68-72.

Arija, H. H. and Perdhana, M. S. (2017) "Pengaruh Desain Kantor Terhadap Produktivitas Karyawan di Puskesmas Batang," Diponegoro Journal of Management, 6(2).

Asnora, F. H. (2020) "Pengaruh Budaya Organisasi, Beban Kerja dan Disiplin Kerja terhadap Produktivitas Kerja Karyawan pada CV. Akademi Mandiri Medan," Ecobisma (Jurnal Ekonomi, Bisnis dan Manajemen), 7(2).

Assiddiqi, L. (2016) "Perancangan Tata Letak Laboratorium Analisis Udara di PT. East Jakarta Industrial Park."

Badan Pusat Statistik (2018) Proyeksi Jumlah Penduduk Indonesia Menurut Kelompok Usia (2015-2045).

Badan Pusat Statistik (2020a) "Pengeluaran untuk Tenaga Kerja Industri Besar dan Sedang Menurut Sub Sektor (Milyar Rupiah), 2000-2017."

Badan Pusat Statistik (2020b) "Proporsi Tenaga Kerja pada Sektor Industri Manufaktur, 2015 - 2019."

Business Matters (2020) How to Improve Productivity through Office Design.

Chandra, E. (2019) Menelusuri Pengaruh Lingkungan Kerja Terhadap Performa Karyawan, Finansialku.

Christian, M. et al. (2021) "Business Performance Determinants of Salted Fish Distribution in Kapuk During the COVID-19," Journal of Distribution Science, 19(6), pp. 29-39. doi: 10.15722/jds.19.6.202106.29.

Darmono, L. A. (2019) Menperin Resmian Pabrik Alat Listrik Tegangan Tinggi Senilai Rp 500 Miliar, Suara Karya.

Daya, M. A., Sitania, F. D. and Profita, A. (2018) "Perancangan Ulang Tata Letak 
Fasilitas Produksi dengan Metode BLOCPLAN (Studi Kasus: UKM Roti Rizki, Bontang)," PERFORMA Media Ilmiah Teknik Industri, 17(2), pp. 140 145. doi: 10.20961/performa.17.2.29664.

Fajrilah, M. E., Aviasti and Nu'man, H. (2017) "Usulan Perbaikan Tata Letak Perkantoran di PT. Brodo Ganesha Indonesia Dengan Menggunakan Software BLOCPLAN (Studi Kasus : PT . Brodo Ganesha Indonesia)," Prosiding Teknik Industri UIB, 3(2), pp. 424-431.

Franklin, N. (2019) Poor Office Design Continues to Hamper Productivity, insight.

Goldberg, D. E. (1989) Genetic Algorithms in Search, Optimization \& Machine Learning. Alabama: Addison-Wesley Publishing Company.

Gunawan, F. E. et al. (2020) "Service Quality Analysis of SMEs Tempe in Province of Jakarta, Indonesia," Technology Reports of Kansai University, 62(7), pp. 38273833.

Hamdani, F., Herlina, L. and Kurniawan, B. (2016) "Usulan Layout Perkantoran Baru Menggunakan Metode Activity Relationship Chart dan BLOCPLAN di PT. Krakatau Bandar Samudera," Jurnal Teknik Industri, 4(2), pp. 4-9.

Hidayat, S. A. and Ariyono, V. (2017) "Usulan Tata Letak Pabrik di PT. Djarum Divisi Workshop (Machine Shop \& Fabrikasi) Akibat Pemindahan Lokasi Pabrik," Prosiding Seminar Nasional Teknologi dan Informatika, 4. doi: 10.2298/PAN0903301G.

Hillier, F. S. and Lieberman, G. J. (2015) Introduction to operations research. 10th ed. New York: McGraw-Hill Education.

Holland, J. H. (1992) Adaptation in Natural and Artificial Systems. Cambridge: Massachusetts Institute of Technology.

HRnews (2020) Workplace Expert Warns of Possible Impact of New Workplace Setups on Employee Productivity.

Inamizu, N. (2015) "Impact of Change in Office Layout on Employees' Communication Satisfaction," Annals of Business Administrative Science, 14, pp. 335-350.

International Labor Organization (2016) Upah dan Produktivitas untuk Pembangunan Berkelanjutan.
Irfan, M. et al. (2020) "Determinants of Labor Productivity for Building Projects in Pakistan," Journal of Construction Engineering, Management \& Innovation, 3(2), pp. 85-100.

Karima, B. R., Khamim, M. and Setiono, J. (2020) "Analisa Produktivitas Tenaga Kerja berdasarkan PERMENPUPR dan Perhitungan Lapangan Pekerjaan Beton Bertulang Proyek Apartemen Bess Mansion," Jurnal Online Skripsi Manajemen Rekayasa Konstruksi Politeknik Negeri Malang, 1(2).

Kasilingam, R. G. (2011) Logistics and Transportation: Design and Planning. New Jersey: Springer Science Business Media.

Kebela, F. T. et al. (2020) "Perbaikan Tata Letak Fasilitas Produksi Incoming Material Menggunakan Systematic Layout Planning di PT. Pan Brothers Tbk. Boyolali," Performa: Media Ilmiah Teknik Industri, 19(1).

Kementerian Ketenagakerjaan Republik Indonesia (2016) Pengukuran Produktivitas Nasional, Regional dan Sektoral. Jakarta: Direktorat Bina Produktivitas Kementrian Ketenagakerjaan.

Kovács, G. (2019) "Layout Design for Efficiency Improvement and Cost Reduction," Bulletin of the Polish Academy of Sciences: Technical Sciences, 67(3), pp. 547-555. doi: 10.24425/bpasts.2019.129653.

Kovács, G. and Kot, S. (2017) "Facility Layout Redesign for Efficiency Improvement and Cost Reduction," Journal of Applied Mathematics and Computational Mechanics, 16(1), pp. 63-74.

Kurangi Ketergantungan Impor Peralatan Listrik, Industri Substitusi Harus Didorong (2017) Dunia Energi.

Lasut, A., Rottie, R. and Kairupan, I. (2019) "Usulan Tata Letak Fasilitas Produksi dengan Metode Systematic Layout Planning," Jurnal Realtech, 15(1), pp. 40-46. doi: 10.1016/b978-0-12-8183649.00019-6.

Lekan, O. K., Kayode, O. I. and Morenikeji, A. A. (2017) "Analysis of Plant Layout Design for Operational Efficiency with CRAFT Algorithms," Acta Universitatis 
Danubius: Oeconomica, 13(4), pp. 1527.

Maheswari, H. and Firdauzy, A. D. (2015) "Evaluasi Tata Letak Fasilitas Produksi untuk Meningkatkan Efisiensi Kerja pada PT. Nusa Multilaksana," Jurnal Ilmiah Manajemen dan Bisnis, 1(3).

Makmun, M. (2018) Indonesia Berpeluang Kembangkan Industri Panel Listrik, Berita Satu.

Mangkunegara, A. . A. P. (2009) Manajemen Sumber Daya Manusia Perusahaan. Bandung: Rosdakarya.

Marlita, E. (2017) "Analisis Faktor yang Memengaruhi Produktivitas Tenaga Kerja dan Dampaknya terhadap Kemiskinan di Indonesia," Jurnal Fakultas Ekonomi dan Manajemen Institut Pertanian Bogor.

Maulina, R. (2019) 7 Tantangan Industri Manufaktur \& Cara Mengatasinya, jurnal.id.

Muslim, D. and Ilmaniati, A. (2018) "Usulan Perbaikan Tata Letak Fasilitas Terhadap Optimalisasi Jarak dan Ongkos Material Handling dengan Pendekatan Systematic Layout Planning (SLP) di PT. Transplant Indonesia," Jurnal Media Teknik dan Sistem Industri, 2(1), p. 45. doi: 10.35194/jmtsi.v2i1.327.

Muther, R. and Hales, L. (2015) Systematic Layout Planning. Marietta: Management and Industrial Research Publications.

Nurprihatin, F., Elnathan, R., et al. (2019) “A Distribution Strategy Using a Two-step Optimization to Maximize Blood Services Considering Stochastic Travel Times," in IOP Conference Series: Materials Science and Engineering. IOP Publishing Ltd. doi: 10.1088/1757899X/650/1/012043.

Nurprihatin, F., Octa, A., et al. (2019) "The Extension Analysis of Natural Gas Network Location-Routing Design Through the Feasibility Study," Journal of Applied Research on Industrial Engineering, 6(2), pp. 108-124. doi: 10.22105/jarie.2019.174164.1082.

Nurprihatin, F. et al. (2021) "Decision Support System for Truck Scheduling in Logistic Network Through Cross-docking Strategy," Journal of Physics: Conference Series, 1811(1). doi: 10.1088/1742-6596/1811/1/012009.
Nurprihatin, F., Angely, M. and Tannady, H. (2019) "Total Productive Maintenance Policy to Increase Effectiveness and Maintenance Performance Using Overall Equipment Effectiveness," Journal of Applied Research on Industrial Engineering, 6(3), pp. 184-199. doi: 10.22105/jarie.2019.199037.1104.

Nurprihatin, F., Jayadi, E. L. and Tannady, H. (2020) "Comparing Heuristic Methods' Performance for Pure Flow Shop Scheduling Under Certain and Uncertain Demand," Management and Production Engineering Review, 11(2), pp. 50-61. doi: 10.24425/mper.2020.133728.

Nurprihatin, F., Regina, T. and Rembulan, G. D. (2021) "Optimizing rice distribution routes in Indonesia using a two-step linear programming considering logistics costs," Journal of Physics: Conference Series, 1811(1). doi: 10.1088/17426596/1811/1/012010.

Nurprihatin, F. and Tannady, H. (2018) “An Integrated Transportation Models and Savings Algorithm to Minimize Distribution Costs," in Proceeding of the 1st Asia Pacific Conference on Research in Industrial and Systems Engineering. Depok: Department of Industrial Engineering Universitas Indonesia, pp. 216-221.

Padmantyo, S., Nursavilla, F. and Ningsih, M. A. (2018) "Pengaturan Ulang Tata Letak Fasilitas Pabrik untuk Meningkatkan Produktivitas (Kasus PT. ASA)," Proceeding of the 8th University Research Colloquium.

Paljug, K. (2020) How to Design a Workspace that Improves Productivity, business.com.

Pramana, D. (2020) "Pengaruh Tata Ruang Kantor terhadap Produktivitas Kerja Pegawai pada Kantor Dinas Kesehatan Daerah Kabupaten Tapanuli Selatan," Jurnal Administrasi dan Perkantoran Modern, 9(2).

Pransuamitra, P. A. (2019) Produktivitas Pekerja Indonesia di ASEAN Urutan Berapa?, CNBC Indonesia.

Putri, M. V. and Djalil, A. N. H. (2019) "Peningkatan Produktivitas Kerja Bagian Surveyor dengan Perbaikan Tata Letak Fasilitas," Jurnal Industri Kreatif, 3(2).

Putri, R. E. and Ismanto, W. (2019) "Pengaruh Perancangan Ulang Tata Letak Fasilitas 
di Area Operasional Kerja Berbasis 5S untuk Pengajuan Modal Usaha," Dimensi, 8(1), pp. 71-89.

Putri, U. H. (2019) Perbaiki Tata Letak Fasilitas pada Perkantoran Kelapa Sawit PT. Socfin Indonesia Kebun Matapao Sumatra Utara. Medan Area University.

Rosyidi, M. R. (2018) "Analisa Tata Letak Fasilitas Produksi dengan Metode ARC, ARD, dan AAD di PT. XYZ," Jurnal Teknik WAKTU, 16(1).

Safirtri, N. et al. (2017) "Analisis Perancangan Tata Letak Fasilitas Produksi menggunakan Metode Activity Relationship Chart," Jurnal Manajemen2, $9(1), \quad$ p. $40 . \quad$ doi: 10.29264/jmmn.v9i1.2431.

Siagian, S. P. (2015) Manajemen Sumber Daya Manusia. 23rd ed. Jakarta: Bumi Aksara.

Siahaan, R. C. and Oktiarso, T. (2018) "Perancangan Tata Letak Lantai Produksi Baru dengan Metode Systematic Layout Planning," Journal of Integrated System, 1(2), pp. 161-179. doi: 10.28932/jis.v1i2.1201.

Siregar, B. P. (2019) Investasi Industri Elektronika Ditargetkan Tembus Rp13 Triliun, Warta Ekonomi.

Sofyan, D. K. and Syarifuddin, S. (2015) "Perancangan Ulang Tata Letak Fasilitas dengan Menggunakan Metode Konvensional Berbasis 5S (Seiri, Seiton, Seiso, Seiketsu dan Shitsuke)," Teknovasi, 2(2), pp. 27-41.

Stephens, M. P. and Matthew P. Stephens (2019) Manufacturing Facilites Design and Material Handling. 6th ed. Indiana: Purdue University Press.

Tahir, S., Syukriah and Baidhawi, S. (2015) "Perbaikan Tata Letak Fasilitas Produksi Menggunakan Algoritma CRAFT," Malikussaleh Industrial Engineering Journal, 4(2), pp. 36-41.
Tannady, H. et al. (2019) "Process Improvement to Reduce Waste in the Biggest Instant Noodle Manufacturing Company in South East Asia," Journal of Applied Engineering Science, 17(2). doi: 10.5937/jaes17-18951.

Tannady, H., Andry, J. F. and Nurprihatin, F. (2020) "Determinants Factors Toward the Performance of the Employee in the Crude Palm Oil Industry in West Sumatera, Indonesia.," in IOP Conference Series: Materials Science and Engineering, pp. 1-5. doi: 10.1088/1757899X/771/1/012066.

Tannady, H., Erlyana, Y. and Nurprihatin, F. (2019) "Effects of Work Environment and Self-efficacy Toward Motivation of Workers in Creative Sector in Province of Jakarta, Indonesia," Quality - Access to Success, 20(172), pp. 165-168.

Tannady, H., Nurprihatin, F. and Hartono, H. (2018) "Service quality analysis of two of the largest retail chains with minimart concept in Indonesia," Business: Theory and Practice, 19, pp. 177-185. doi: 10.3846/BTP.2018.18.

Tompkins, J. A., White, J. A. J. A. and Bozer, Y. . (2010) Facilities Planning. New Jersey: John Wiley \& Sons, Inc.

Umar, H. (2018) Riset Sumber Daya Manusia dalam Organisasi. Jakarta: PT. Gramedia Pustaka Utama.

Wignjosoebroto, S. (2003) Ergonomi Studi Gerak dan Waktu. Surabaya: Guna Widya.

Winarno, H. (2015) "Analisis Tata Letak Fasilitas Ruang Teknik Universitas Serang Raya dengan Menggunakan Metode Activity Relationship Chart (ARC)," Seminar Nasional Sains dan Teknologi. 